\title{
Axial Compression Tests on Corroded Reinforced Concrete Columns Consolidated with Fibre Reinforced Polymers
}

\author{
B. Ding*
}

Architectural Engineering Department, Wenzhou Vocational \& Technical College, Zhejiang, Wenzhou 325 000, P.R. China

\begin{abstract}
\| Abstract
Reinforced concrete structure featured by strong bearing capacity, high rigidity, good integrity, good fire resistance, and extensive applicability occupies a mainstream position in contemporary architecture. However, with the development of social economy, people need higher requirements on architectural structure; durability, especially, has been extensively researched. Because of the higher requirement on building material, ordinary reinforced concrete structure has not been able to satisfy the demand. As a result, some new materials and structures have emerged, for example, fibre reinforced polymers. Compared to steel reinforcement, fibre reinforced polymers have many advantages, such as high tensile strength, good durability, good shock absorption, low weight, and simple construction. The application of fibre reinforced polymers in architectural structure can effectively improve the durability of the concrete structure and lower the maintenance, reinforcement, and construction costs in severe environments. Based on the concepts of steel tube concrete, fibre reinforced composite material confined concrete, and fibre reinforced composite material tubed concrete, this study proposes a novel composite structure, i.e., fibre reinforced composite material and steel tube concrete composite structure. The structure was developed by pasting fibre around steel tube concrete and restraining core concrete using fibre reinforced composite material and steel tubes. The bearing capacity and ultimate deformation capacity of the structure was tested using column axial compression test.
\end{abstract}

\section{$\|$ Keywords}

Fibre reinforced polymers, carbon fibre sheet, axial compression, concrete, corroded reinforced steel

\section{Introduction}

With the constant development of social economy, the construction scale of high-rise buildings and long-span structures with good performance and strong flexibility becomes more important. Besides the requirements on bearing capacity, durability, plasticity and toughness, problems of long-span and high-rise structures, such as effective utilization of service space, reasonable structural form and weight reduction, need to be solved as well. The advancement of technology must provide powerful technological support for new possibilities.

Steel-concrete composite structure, ${ }^{1-3}$ fibre reinforced composite material confined concrete ${ }^{4-6}$ and fibre reinforced composite material tubed reinforced concrete ch $^{7-9}$ are novel composite structures that have emerged to adapt to the new requirements of modern engineering structure and construction technology industrialization. Compared to the traditional reinforced concrete, steel tube concrete featured by high bearing capacity, good plasticity, good toughness, simple construction, strong fire resistance and high economic effect can satisfy the development demand of architectural structures towards high height, long span, and heavy load, and is applicable to high-rise and super

${ }^{*}$ Bin Ding

e-mail: dingbindb2016@sina.com high-rise buildings and bridge structures, especially buildings in seismic regions. Owing to their high tensile strength and the ability to bind with concrete of fibre reinforced composite material, fibre reinforced composite material confined concrete and fibre reinforced composite material tubed reinforced concrete have significantly improved bearing capacity and durability. In addition, they are featured by convenient use, long endurance, corrosion resistance, wide application, effective special utilization, and low weight. Currently, these two kinds of concrete are extensively applied for reinforcement of existing structures. Furthermore, fibre reinforced composite material can also be used in newly built structure. Fibre reinforced composite material based tube can also be used as the template for pouring core concrete, which can improve structural bearing capacity, enhance the ductility of concrete and accelerate construction. ${ }^{10-12}$

Corrosion of reinforcement is the major cause of decreased durability of concrete structures. A large number of concrete structures are bound to be repaired, reinforced or even removed due to the corrosion of reinforcement. Fibre reinforced composite material characterized by strong resistance to corrosion and fatigue, high strength and light weight, convenient construction and high chemical stability gradually become the preferred material for repairing and reinforcing structures. ${ }^{13,14}$ If a concrete structure is reinforced by fibre reinforced composite material, further 
corrosion of steel reinforcement will be slowed down, and the ductility and mechanical properties of the component can be significantly improved. ${ }^{15,16}$ Based on the concepts of steel tube concrete, fibre reinforced composite material confined concrete and fibre reinforced composite material tubed concrete, this study proposes a new composite structure, i.e., fibre reinforced composite material and steel tube concrete composite structure. The structure was developed by pasting fibre around steel tube concrete and restraining core concrete using fibre reinforced composite material and steel tubes. The bearing capacity and ultimate deformation capacity of the structure were tested using column axial compression test. Fibre reinforced composite material confined steel tube concrete column plays an important role in civil engineering and has been directly applied for reinforcing existing structures or replacing steel reinforcements or steel tubes. It can strongly confine core concrete, delay the bending of steel tube, and prevent corrosion of steel tube.

\section{Test on corroded reinforced concrete columns consolidated with fibre reinforced polymers}

The aim was to test the changes in parameters, such as the category of fibre cloth and corrosion rate, and record the test data under different parameters. The test included: corrosion test on reinforced concrete column, test on axial compression of corroded reinforced concrete column, and test on actual corrosion rate of column reinforcement. Table 1 shows the parameters of different test specimens.

Table 1 - Parameters of different specimens

\begin{tabular}{c|c|c|c|c}
\hline Specimen & $\begin{array}{c}\text { Concrete } \\
\text { strength } \\
\text { grade }\end{array}$ & $\begin{array}{c}\text { Thickness } \\
\text { of steel pipe } \\
\text { wall, } \\
t / \mathrm{mm}\end{array}$ & $\begin{array}{c}\text { Length of } \\
\text { specimens, } \\
\text { L/mm }\end{array}$ & $\begin{array}{c}\text { Diameter of } \\
\text { cross section, } \\
D / \mathrm{mm}\end{array}$ \\
\hline 0-c & C40 & 6 & 2016 & 168 \\
C2-C & C40 & 6 & 2016 & 168 \\
C2-s & C40 & 6 & 588 & 168 \\
G2-C & C40 & 6 & 2016 & 168 \\
G2-s & C40 & 6 & 588 & 168 \\
\hline
\end{tabular}

$\mathrm{C}$ and $\mathrm{G}$ refer to carbon fibre reinforced polymer (CFRP) fibre cloth and glass fibre reinforced polymer (GFRP) fibre cloth, respectively; 0 and 2 refer to the number of sheet layers; $c$ and s refer to slenderness ratio. CFRP fibre cloth is featured by brittle failure, and concentrated and regular fracture; GFRP cloth fibre with a stronger tenacity is featured by tearing failure, irregular fracture, and large distance of fracture position between the strands.

\subsection{The manufacture of specimen}

Before manufacture, the selected steel tube was cut into the needed lengths keeping the sections of the two ends smooth. Two pieces of steel cover plates, which were larger than the section of the corresponding test specimen, were then cut same as the cover plates of the test specimen. Every test specimen had a corresponding cover plate. One end of the steel tube was then welded with the cover plate; the other end of the steel tube was also welded after concrete pouring. The geometric centres of the cover plate and the steel tube were aligned during welding. As concrete would contract during maintenance, the surface of concrete should be higher than the section of the steel tube during pouring, and polished and levelled after hardening. Self-mixing concrete was used. For electrochemical corrosion, the pouring of the test specimen was conducted twice. The first time, the short column body was poured, followed by seven days of maintenance. After the form was removed, it was naturally maintained for one month. After the concrete strength had fully developed, the electrochemical corrosion experiment on longitudinal reinforcement and hoop reinforcement was carried out, respectively. The second time the pouring of the ground beam was performed after the reinforcement of the column body had corroded. After that, the concrete was maintained using the natural maintenance method. The surface of steel tube was pasted with fibre cloth after 28 days of maintenance, as shown in Fig. 1.

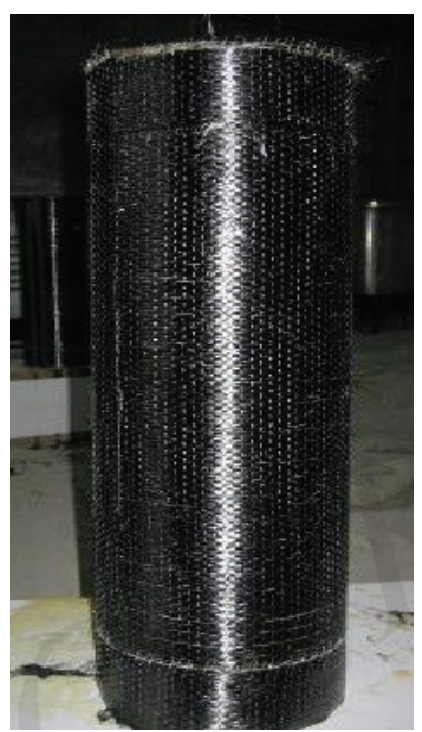

Fig. 1 - Fibre cloth covered reinforced concrete column

\subsection{Corrosion}

After maintenance, the reinforced concrete column was taken out and put into a cool and dark place $\left(15^{\circ} \mathrm{C}, 50 \%\right)$. The reinforcement corrosion test was carried out using electric flux in combination with reliability cantered maintenance to reach a corrosion rate of $0 \%, 5 \%, 10 \%$, and $15 \%$, respectively. 
A simple electrochemical circuit composed of direct current stabilized the power supply, a plastic box, stainless steel plate electrode, wire and electrolyte $(\mathrm{NaCl}$ solution with a mass fraction of $5 \%$ ) was used in the electrochemical corrosion test. Prior to the corrosion experiment, the whole section of the reinforced concrete column test specimen was immersed into a pool loaded with electrolyte and the test specimens were in parallel connection. After three days of soaking, direct current was connected. The columns were connected in parallel. As to the circuit of the electrochemical corrosion, stainless steel was used as cathode and steel reinforcement as anode. Cathode and anode formed an electrochemical circuit through $\mathrm{NaCl}$ electrolyte. Under the effect of impressed current, the electrons released by the steel reinforcement at the anode were oxidized, i.e., corroded. The corrosion current and voltage of reinforcement were monitored by a constant-voltage potential meter. With the increase in the corrosion rate, the corrosion conditions needed to be observed more frequently until the preset corrosion rates $0 \%, 5 \%, 10 \%$ and $15 \%$ were reached. ${ }^{17-19}$

\subsection{Experimental scheme}

Experimental instruments: MTS electro-hydraulic servo program control structure testing machine (NCS Testing Technology Co., Ltd., China) was used. Rectangular loading plate on the upper and lower ends of combination column was loaded using a hydraulic car. Fine sand was used for levelling before loading.

The arrangement of measuring points: One vertical resistance strain gauge and one ring resistance strain gauge were pasted at symmetric positions of the lateral central section of the test specimen to test the axial and ring strains of the central section of the test specimen. Two vertical displacement meters were installed at symmetric displacement on two sides of the test specimen. The longitudinal strain of the test specimen during axial compression was measured.

Main content of measurement: The pressure data generated under different levels of load were collected into the computer using a pressure sensor. Vertical deformation data generated under different levels of load were collected into computer using a displacement sensor and an axial strain gauge. Ring strain data of the middle part of the external surface of the basalt fibre reinforced polymer (BFRP) - polyvinyl chloride (PVC) tube self-compacting regenerated concrete short column under different levels of load were collected into computer using a ring strain gauge.

\subsection{Loading scheme}

To set a fixed support at the bottom of the column, the test specimen was fixed by two pairs of foundation bolts. The axial load at the top of the column was exerted by an oil jack installed on the cross beam of the reaction frame. The axial force was kept stable during the test. During loading, a sliding car in the upper part moved horizontally along with the movement of MTS actuator. The loading head always acted on the section centroid of the capital. Prior to loading, geometric centring was performed to make the axis of the test specimen coincide with the centre line of loading acting force direction. When the load of the test column was $30 \%$ of the ultimate bearing capacity, physical centring was performed. The strain on the two sides of the section in the middle of the test specimen was observed and measured to make the axial direction of the test specimen coincide with the direction of loading acting force in the process of constant adjustment, and achieve an even strain on the two sides of the section of the test column during loading. The loading instruments and the data acquisition instruments should be ensured at a normal working state; timely exchange was needed in case of damage. To cope with some emergency situations, the test workers were required to be familiar with the operation process.

The test column was loaded using monotonic static test according to the step load system. Generally, $10 \%$ of the ultimate bearing capacity of the test column was taken as the loading value at every level. The loading at every level was held for $90 \mathrm{~s}$. When the load reached $80 \%-90 \%$ of the estimated ultimate bearing capacity, a slow-speed continuous loading system was used until the component was damaged. ${ }^{20-22}$

\subsection{The detection of actual corrosion rate of reinforcement}

After the axial compression test, the internal reinforcements were taken out carefully. Attachments on the surface of the reinforcement were cleaned using a wire brush. Acid washing was then performed using $12 \%$ diluted hydrochloric acid solution, followed by washing with water, neutralization with whitewash, and washing with water. The corroded reinforcement was dried for $2 \mathrm{~h}$ in a drying oven, and the final quality was weighed using an electronic scale with a precision of $0.1 \mathrm{~g} \cdot{ }^{23-25}$ The average section loss rate and quality loss rate were approximately equal, and both smaller than the loss rate of the weakest section of the reinforcement. Many studies have suggested that the loss rate of the weakest section was the lack of integrity and uniformity. Therefore, the Faraday formula was used to calculate the actual quality loss rate of the reinforcement, as shown in Eq. (1).

$$
L_{w} / \%=\frac{\omega_{0}-\omega-\frac{\left(\omega_{01}-\omega_{1}\right)+\left(\omega_{02}-\omega_{2}\right)}{2}}{\omega_{0}} \times 100
$$

where $L_{w}$ refers to the quality loss rate of steel reinforcement corrosion, accurate to $0.01, \omega_{0}$ refers to the quality before steel reinforcement corrosion, $\omega$ refers to the quality of corroded steel reinforcement after acid washing, $\omega_{01}$ and $\omega_{02}$ stand for the initial quality of two steel reinforcements used for baseline correction, and $\omega_{1}$ and $\omega_{2}$ stand for the quality of two steel reinforcements used for baseline correction after acid washing. 


\section{Result analysis}

Table 2 shows the test results of the test specimens.

\subsection{Load-intra-column lateral deflection curve analysis}

Fig. 2 shows the load-intra-column lateral deflection curves of test specimens 0 -c and C2-c. The lateral deflection generated by fibre reinforcement composite material and steel tube concrete composite middle long column test specimen $\mathrm{C} 2-\mathrm{c}$ at the beginning of load-bearing developed slowly due to the initial defects of the test specimen; the load-intra-column lateral reflection curve was almost linear; this stage was called the elastic working stage. When the load of the test column reached $70 \%$ of the ultimate load, the load-intra-column lateral deflection curve began to develop deviating from a straight line. Moreover, the slope of the curve gradually increased; this stage was called the elastic-plastic working stage. When the load exceeded $70 \%$ and became close to the ultimate load, the curve tended to be stable and the development of the load-intra-column deflection accelerated. Eventually when the load reached the ultimate value, the test specimen failed due to the excessively large lateral deformation.

\subsection{Load-average longitudinal strain curve analysis}

Average longitudinal strain, i.e., longitudinal deformation rate, refers to the ratio of the longitudinal compression deformation of the test specimen to the initial length of the test specimen. Fig. 3 shows the load-average longitudinal strain curves of test specimens $\mathrm{C} 2-\mathrm{s}, \mathrm{C} 2-\mathrm{C}$, and $\mathrm{O}-\mathrm{C}$. For the fibre reinforced composite material and steel tube concrete composite middle long column test specimen, the longitudinal strains of all measuring points were closely under the same grade of load at the initial stage. With the increase in load, the longitudinal strains of all measuring

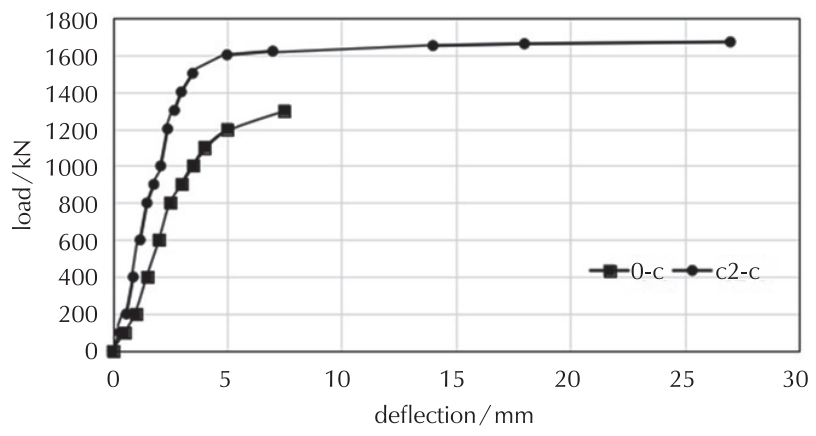

Fig. 2 - Load-intra-column lateral deflection curves



Fig. 3 - Load-average radial strain curves

points demonstrated a difference, and the curve began to develop deviating from a straight line, under the same grade of load under the influence of factors such as initial defect and accidental eccentricity. When the load reached ultimate value, the average longitudinal strain increased sharply until the test specimen failed due to the excessively large lateral deformation.

Table 2 - Test results of the test specimens

\begin{tabular}{|c|c|c|c|c|}
\hline Specimen & $\begin{array}{l}\text { Category and dose of } \\
\text { fibre reinforcement } \\
\text { composite material }\end{array}$ & $\begin{array}{l}\text { Slenderness ratio } \\
\quad(\lambda=4 L / D)\end{array}$ & $\begin{array}{c}\text { Ultimate bearing } \\
\text { capacity/kN }\end{array}$ & Failure mode \\
\hline $0-\mathrm{c}$ & - & 48 & 1350 & $\begin{array}{l}\text { elasto-plastic } \\
\text { instability }\end{array}$ \\
\hline $\mathrm{C} 2-\mathrm{C}$ & $\begin{array}{l}\text { two-layer fibre } \\
\text { reinforcement } \\
\text { composite material }\end{array}$ & 48 & 1630 & $\begin{array}{l}\text { elasto-plastic } \\
\text { instability }\end{array}$ \\
\hline C2-s & $\begin{array}{l}\text { two-layer fibre } \\
\text { reinforcement } \\
\text { composite material }\end{array}$ & 14 & 2360 & $\begin{array}{l}\text { material strength } \\
\text { failure }\end{array}$ \\
\hline G2-c & $\begin{array}{l}\text { two-layer fibre } \\
\text { reinforcement } \\
\text { composite material }\end{array}$ & 48 & 1550 & $\begin{array}{l}\text { elasto-plastic } \\
\text { instability }\end{array}$ \\
\hline G2-s & $\begin{array}{l}\text { two-layer fibre } \\
\text { reinforcement } \\
\text { composite material }\end{array}$ & 14 & 2500 & $\begin{array}{l}\text { material strength } \\
\text { failure }\end{array}$ \\
\hline
\end{tabular}


Fig. 2 suggests that, compared to ordinary steel tube concrete middle long column, the elastic working range of fibre reinforced composite material and steel tube concrete composite middle long column was larger; the slope of the load-intra-column lateral deflection curve was larger in the elastic stage; in the entire loading process, the test specimen with certain deflection had higher load; therefore, the load increased, i.e., the bending rigidity significantly increased. In addition, larger lateral deflection deformation produced in the composite middle long column before the load reached its ultimate value; the deformation developed quickly, and the curve became much gentler when the test specimen was close to failure. This indicated that the lateral restraint effect of fibre cloth improved the bearing capacity and ductility of the component. Fig. 3 suggests that, compared to the load-average longitudinal strain curve of the short column test specimen, the longitudinal strain of fibre reinforced composite material and steel tube concrete composite middle long test specimen developed faster under the effect of initial defects in the elastic-plastic stage, exceeding the load-average longitudinal strain curve; the bearing capacity and ultimate deformation ability of the test specimen were significantly improved.

\subsection{Load-axial strain curve}

Fig. 4 suggests that, when the load of the column consolidated by carbon fibre reinforced polymers and glass fibre reinforced polymers with different corrosion rates was smaller than $150 \mathrm{kN}$, the load - axial strain curve changed linearly, and the concrete demonstrated linear elastic strain in that period; when the load was larger than $300 \mathrm{kN}$, the concrete was in plastic deformation stage and the strain increased with the increase in load. It may be seen from C2-15\% load - radial strain curve that, when the load was smaller than $150 \mathrm{kN}$, the strains of column fibre cloth and concrete were basically the same, but then increased with the increase in load, indicating that damage to the concrete in the middle of column had begun. When the load reached failure load, the strain of concrete in the middle of column demonstrated a horizontal tendency; C2-15\% column was thoroughly damaged when the concrete was crushed.

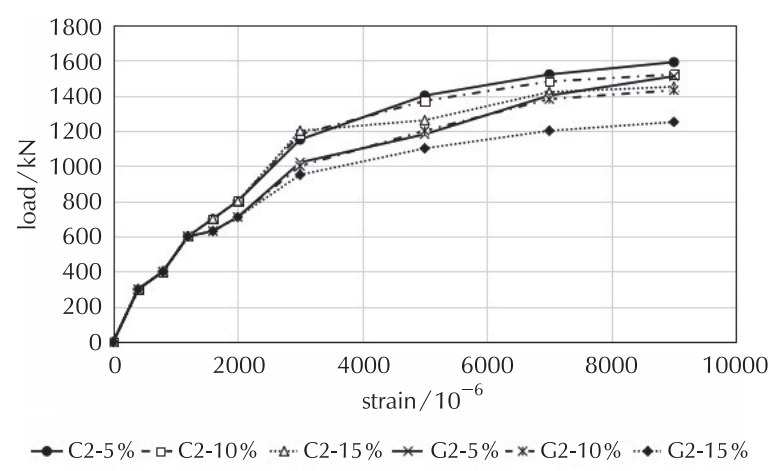

Fig. 4 - Load-axial strain curves of column consolidated by carbon fibre reinforced polymers (C2) and glass fibre reinforced polymers (G2) under different corrosion rates

\subsection{Mass loss rate of rebar}

The longitudinal bars of the column were weighed, and the average value was regarded as the final result. The mass loss rate of the rebar was then calculated (Table 3).

Table 3 - Mass of corroded rebar

\begin{tabular}{c|c|c|c|c}
\hline Specimen no. & $0 \%$ & $5 \%$ & $10 \%$ & $15 \%$ \\
\hline 0-c & $136 \mathrm{~g}$ & $124 \mathrm{~g}$ & $114 \mathrm{~g}$ & $119 \mathrm{~g}$ \\
$\mathrm{C} 2-\mathrm{c}$ & $137 \mathrm{~g}$ & $123 \mathrm{~g}$ & $116 \mathrm{~g}$ & $118 \mathrm{~g}$ \\
$\mathrm{C} 2-\mathrm{s}$ & $136 \mathrm{~g}$ & $6 \mathrm{~g}$ & $588 \mathrm{~g}$ & $168 \mathrm{~g}$ \\
$\mathrm{G} 2-\mathrm{c}$ & $137 \mathrm{~g}$ & $6 \mathrm{~g}$ & $2016 \mathrm{~g}$ & $168 \mathrm{~g}$ \\
G2-s & $137 \mathrm{~g}$ & $6 \mathrm{~g}$ & $588 \mathrm{~g}$ & $168 \mathrm{~g}$ \\
average value & $136.6 \mathrm{~g}$ & $123.8 \mathrm{~g}$ & $115.6 \mathrm{~g}$ & $118 \mathrm{~g}$ \\
mass loss rate & $0 \%$ & $9.3 \%$ & $15.4 \%$ & $13.6 \%$ \\
\hline
\end{tabular}

Table 3 suggests that, when the theoretical corrosion rate was equal to or smaller than $10 \%$, the actual corrosion rate was larger than the theoretical corrosion rate. When the theoretical corrosion rate was equal to $15 \%$, the actual corrosion rate was smaller than the theoretical corrosion rate.

\section{Conclusion}

In reality, reinforced concrete usually corrodes under the induction of micro-crack corrosion. The comparison of the columns consolidated by glass fibre reinforced polymers and carbon fibre reinforced polymers with a corrosion rate of $10 \%$ suggested that, when the number of consolidation layers and corrosion rates were the same, the ultimate load of carbon fibre reinforced polymers was larger than that of glass fibre reinforced polymers; the load improvement rate of the column consolidated by carbon fibre reinforced polymers was higher than that of the column consolidated by glass fibre reinforced polymers. When the load reached the failure load value, the head of the column consolidated by carbon fibre reinforced polymers and the concrete in the middle of the column were crushed, but the carbon fibre reinforced polymers cloth was not broken. These findings suggested that the axial restraint effect of carbon fibre reinforced polymers was better than that of glass fibre reinforced polymers, i.e., the consolidation effect of carbon fibre reinforced polymers was better. Compared to the ordinary steel tube concrete middle long column test specimen, the ultimate average radial strain of the fibre reinforced composite material and steel tube concrete composite middle long column test specimen was significantly improved, suggesting the restraint effect of fibre cloth improved the ultimate deformation ability of the middle long column. Therefore, fibre reinforced polymers can improve the performance of concrete members. 


\section{ACKNOWLEDGEMENT}

This work was supported by Zhejiang Provincial Natural Science Foundation (Project No. LY13E080020; Project Name: Research on the Calculation Model for FRP-confined Rectangular Concrete columns).

\section{List of symbols and abbreviations}

$$
\begin{array}{ll}
\text { BFRP } & \text { - basalt fibre reinforced polymer } \\
\text { CFRP } & \text { - carbon fibre reinforced polymers } \\
\text { GFRP } & - \text { glass fibre reinforced polymers } \\
\text { MTS } & - \text { material test system } \\
\text { PVC } & - \text { polyvinyl chloride } \\
L_{\mathrm{w}} & - \text { quality loss rate of steel reinforcement corrosion, } \% \\
\omega & - \text { quality of corroded steel reinforcement after acid } \\
& \quad \text { washing, g } \\
\omega_{0} & - \text { quality before steel reinforcement corrosion, g } \\
\omega_{01}, \omega_{02} & \begin{array}{l}
\text { initial quality of two steel reinforcements used for } \\
\text { baseline correction, g }
\end{array} \\
\omega_{1}, \omega_{2} & - \text { quality of two steel reinforcements used for baseline } \\
& \text { correction after acid washing, g }
\end{array}
$$

\section{References \\ Literatura}

1. J. P. Lin, J. F. Wang, R. Q. Xu, Cohesive Zone Model Based Numerical Analysis of Steel-Concrete Composite Structure Push-Out Tests, Math. Probl. Eng. 2014 (11) (2014) 1-12, doi: https://doi.org/10.1155/2014/175483.

2. Y. X. Liang, X. L. Wang, C. Wu, Z. G. Lv, Study on the Impact Properties of a New Debris Flow Dam Based on Steel-Concrete Composite Structure, Appl. Mech. Mater. 638-640 (2014) 2056-2059, doi: https://doi.org/10.4028/ www.scientific.net/AMM.638-640.2056.

3. X. Wei, L. Xiao, K. F. Shao, S. Jiang, Fatigue Performance of Perfobond Shear Connector in Steel-concrete Composite Structure, China J. Highw. Transp. 26 (6) (2013) 96-102, http://zgglxb.chd.edu.cn/EN/Y2013/V26/I6/96.

4. A. Athanasopoulou, G. Parra-Montesinos, Experimental Study on the Seismic Behaviour of High-Performance Fibre-Reinforced Concrete Low-Rise Walls, ACI Struct. J. 110 (5) (2013) 767-778, https://doi.org/10.14359/51685830.

5. S. M. Islam, R. R. Hussain, M. A. Z. Morshed, Fiber-reinforced concrete incorporating locally available natural fibers in normal- and high-strength concrete and a performance analysis with steel fiber-reinforced composite concrete, J. Compos. Mater. 46 (1) (2012) 111-122, doi: https://doi.org/10.1177/0021998311410492.

6. C. A. Weaver, W. G. Davids, H. J. Dagher, Testing and Analysis of Partially Composite Fiber-Reinforced Polymer-Glulam-Concrete Bridge Girders, J. Bridge Eng. 9 (4) (2014) 316-325, doi: https://doi.org/10.1061/(ASCE)10840702(2004)9:4(316).

7. G. Hegemier, L. Stewart, Chapter 30 - Application of fiber-reinforced polymers to reinforced concrete bridges, in
J. Pipinado (Ed.), Innovative Bridge Design Handbook, 2016, pp. 777-794, doi: https://doi.org/10.1016/b978-012-800058-8.00030-х.

8. H. Thomsen, E. Spacone, S. Limkatanyu, G. Camata, Failure Mode Analyses of Reinforced Concrete Beams Strengthened in Flexure with Externally Bonded Fiber-Reinforced Polymers, J. Compos. Constr. 8 (2) (2004) 123-132, doi: https://doi.org/10.1061/(ASCE)10900268(2004)8:2(123).10.14359/51685830.

9. H. S. Kim, Y. S. Shin, Flexural behavior of reinforced concrete (RC) beams retrofitted with hybrid fiber reinforced polymers (FRPs) under sustaining loads, Compos. Struct. 93 (2) (2011) 802-811, doi: https://doi.org/10.1016/j. compstruct.2010.07.013.

10. D. Kalla, J. Sheikh-Ahmad, J. Twomey, Prediction of cutting forces in helical end milling fiber reinforced polymers, Int. J. Mach. Tool. Manu. 50 (10) (2010) 882-891, doi: https://doi.org/10.1016/j.ijmachtools.2010.06.005.

11. B. R. Loyola, V. L. Saponara, K. J. Loh, In situ strain monitoring of fiber-reinforced polymers using embedded piezoresistive nanocomposites, J. Mater. Sci. 45 (24) (2010) 6786-6798, doi: https://doi.org/10.1007/s10853-0104775-y.

12. C. Unterweger, O. Brüggemann, C. Fürst, Synthetic fibers and thermoplastic short-fiber-reinforced polymers: Properties and characterization, Polym. Compos. 35 (2) (2014) 227-236, doi: https://doi.org/10.1002/pc.22654.

13. L. Medina, R. Schledjewski, A. K. Schlarb, Process related mechanical properties of press molded natural fiber reinforced polymers, Compos. Sci. Technol. 69 (9) (2009) 1404-1411, doi: https://doi.org/10.1016/j.compscitech.2008.09.017.

14. M. Romanowicz, Progressive failure analysis of unidirectional fiber-reinforced polymers with inhomogeneous interphase and randomly distributed fibers under transverse tensile loading, Compos. Part A Appl. Sci. Manuf. 41 (12) (2010) 1829-1838, doi: https://doi.org/10.1016/j.compositesa.2010.09.001.

15. F. Oudah, R. El-Hacha, Research progress on the fatigue performance of RC beams strengthened in flexure using Fiber Reinforced Polymers, Compos. Part B Eng. 47 (3) (2013) 82-95, doi: https://doi.org/10.1016/j.compositesb.2012.09.057.

16. G. C. Manos, K. Katakalos, V. Kourtides, The Influence of Concrete Surface Preparation when Fiber Reinforced Polymers with Different Anchoring Devices are Being Applied for Strengthening R/C Structural Members, Appl. Mech. Mater. 82 (2011) 600-605, doi: https://doi.org/10.4028/ www.scientific.net/AMM.82.600.

17. A. Bousselham, O. Chaallal, Behavior of reinforced concrete T-beams strengthened in shear with carbon fiber-reinforced polymer - An experimental study, ACl Struct. J. 103 (3) (2006) 339-347, doi: https://doi. org/10.14359/15311.

18. R. A. Hawileh, H. A. Rasheed, J. A. Abdalla, A. K. Al-Tamimi, Behavior of reinforced concrete beams strengthened with externally bonded hybrid fiber reinforced polymer systems, Mater. Des. 53 (1) (2014) 972-982, doi: https:// doi.org/10.1016/j.matdes.2013.07.087.

19. E. U. Chowdhury, L. A. Bisby, M. F. Green, V. K. Kodur, Residual Behavior of Fire-Exposed Reinforced Concrete Beams Prestrengthened in Flexure with Fiber-Reinforced Polymer Sheets, J. Compos. Constr. 12 (1) 
(2008) 61-68, doi: https://doi.org/10.1061/(ASCE)10900268(2008)12:1(61).

20. J. Li, J. Gong, L. Wang, Seismic behavior of corrosion-damaged reinforced concrete columns strengthened using combined carbon fiber-reinforced polymer and steel jacket, Constr. Build. Mater. 23 (7) (2009) 2653-2663, doi: https://doi.org/10.1016/j.conbuildmat.2009.01.003.

21. Y. Zhou, M. Gou, F. Zhang, S. Zhang, D. Wang, Reinforced concrete beams strengthened with carbon fiber reinforced polymer by friction hybrid bond technique: Experimental investigation, Mater. Des. 50 (17) (2013) 130-139, doi: https://doi.org/10.1016/j.matdes.2013.02.089.

22. O. Rosenboom, S. H. Rizkalla, Experimental study of intermediate crack debonding in fiber-reinforced polymer strengthened beams, ACI Struct. J. 105 (1) (2008) 41-50, doi: https://doi.org/10.14359/19067.

23. V. Garcia, R. François, M. Carcasses, P. Gegout, Potential measurement to determine the chloride threshold concentration that initiates corrosion of reinforcing steel bar in slag concretes, Mater. Struct. 47 (9) (2014) 1483-1499, doi: https://doi.org/10.1617/s11527-013-0130-5.

24. W. Aperador, J. H. Bautista-Ruiz, A. E. Delgado, Monitoring Corrosion of Concrete Embedded Steel obtained from Industrial Product Wastes, Inf. Technol. 24 (4) (2013) 55-66, doi: https://doi.org/10.4067/S0718-07642013000400007.

25. X. F. Song, D. Zhang, T. Sh. He, Corrosion behaviour of reinforcing steel embedded in a concrete surface treated by in situ synthesised super-absorbent resin, Mag. Concrete Res. 65 (1) (2013) 63-70, doi: https://doi.org/10.1680/ macr.12.00035.

\section{SAŽETAK \\ Ispitivanje djelovanja aksijalnog tlaka na korodirane betonske stupove ojačane polimerima mikroarmiranim vlaknima \\ Bin Ding}

U modernoj arhitekturi važnu ulogu imaju ojačani betonski elementi zbog velike nosivosti, krutosti, vatrootpornosti i široke primjenjivosti. S razvojem socioekonomskih prilika ti se zahtjevi povećavaju, a posebno se istražuje trajnost. Strože uvjete koje moraju ispuniti građevni materijali ne mogu zadovoljiti uobičajene ojačane betonske strukture pa su razvijeni novi materijali, npr. vlaknima mikroarmirani polimeri. U usporedbi s čeličnom armaturom, polimeri armirani vlaknima imaju više prednosti: visoku vlačnu čvrstoću, trajni su, dobro apsorbiraju udarce, lagani su i jednostavne konstrukcije. Primjenom vlaknima armiranih polimera može se povećati trajnost betonskih elemenata te smanjiti troškove.

Ovdje su predložene nove kompozitne strukture, tj. kompozitni materijal mikroarmiran vlaknima i betonski kompozitni element s čeličnom cijevi. Strukturni su elementi izgrađeni postavljanjem vlakana oko betona ovijenog čeličnom cijevi i učvršćivanjem betonske jezgre kompozitnim materijalom armiranim vlaknima i čeličnim cijevima. Nosivost i krajnja deformacija istraženi su aksijalnim tlačenjem.

Ključne riječi

Polimeri mikroarmirani vlaknima, ploča od ugljičnih vlakana, aksijalno tlačenje, beton, korodirani armirajući čelik

Architectural Engineering Department, Wenzhou Vocational \& Technical College, Zhejiang Wenzhou 325000 Kina
Stručni rad

Prispjelo 20. veljače 2017. Prihvaćeno 9. svibnja 2017. 